\title{
Protection of River Sitnica From Urban Wastewaters
}

\author{
Besime Sh. Kajtazi and Tania Floqi
}

\section{ABSTRACT}

\begin{abstract}
Wastewater treatment is a growing problem in Kosovo. Pollution from urban wastewaters poses the greatest pressure on Kosovo rivers and their better management represents an important area of improving their ecological status. Kosovo is lacking behind in terms of achieving certain goals and implementing European Environmental Directives, especially the Water Framework Directive and Urban Wastewater Treatment Directive. The lack of wastewater treatment prior to their discharges into receiving waters presents a gap in the water sector which needs to be addressed in order to meet European standards. Kosovo, as a country with a European perspective, must approach this issue as soon as possible. According to the reports of water utilities companies, the level of sewerage services in the country is $65 \%$ while the level of wastewater treatment is $0.7 \%$ [3]. The National Water Strategy [1] aims at protecting water resources through treating wastewater before returning to the nature. According to this strategy, a number of wastewater treatment plants and accompanying infrastructure for main cities should be build. River Sitnica is main river stretching in Kosovo valley, where main urban areas are located including capital Prishtina. With aim of protection the quality of river Sitnica, a study for collection of sewage and wastewater treatment plant for capital Prishtina was prepared and its findings will be presented in this article.
\end{abstract}

Keywords: Clean rivers; urban wastewater; wastewater management.
Published Online: April 26, 2021

ISSN: $2684-446 \mathrm{X}$

DOI : 10.24018/ejgeo.2021.2.2.132

Besime Sh. Kajtazi*

(e-mail: besime.kajtazi@gmail.com)

Tania Floqi

Department of Engineering and

Architecture, Faculty of Engineering, Informatics and Architecture, European University of Tirana, Albania.

(e-mail: tania.floqi@ uet.edu.al)

*Corresponding Author

\section{INTRODUCTION}

Main sources of rivers pollution in Kosovo remain untreated urban and industrial water discharges, accompanied by solid waste, fertilizers, and pesticides [2]. Wastewater collection rate is $65 \%$ and currently only $0,7 \%$ of the entire population has access to wastewater treatment services [3]. Even though Prishtina is the capital of Kosovo and is home to 330,000 citizens, there is no wastewater treatment services available. Consequently, all raw untreated wastewater drains into the Sitnica river. Sitnica is the main river stretching in Kosovo valley that confluence with Ibar, one of main river basins in Kosovo which further flows towards north of country and joins Morava in Serbia which later confluences with Danub river. The watershed covers a total area of $2,873 \mathrm{~km}^{2}$, or about $25 \%$ of the total area of Kosovo. Sitnica is lowland river with very variable flow, being very low during summer $0,5 \mathrm{~m}^{3} / \mathrm{s}$ while during winter reaches up to $328 \mathrm{~m}^{3} / \mathrm{s}$. As recipient of urban wastewater from all surrounding living areas, the river provides some natural settlement and treatment of wastewater well before the flows reach the larger recipient rivers.

Urban wastewaters from the largest part of Prishtina city is discharged into the Vellusha, Prishtevka and Matiqan streams before reaching the Sitnica river west of Fushë Kosovë. The urban areas in Prishtina have expanded quickly in the last two decades. This has created a pressure as many smaller unplanned sewer networks have been added to the system. One issue that Prishtina faces is the cross connection of the rainwater system into the sewer system. Due to the many new buildings and lack of enforcement of building regulation large volumes of rainwater enter the sewer system during storms, causing floods.

\section{METHODS AND MATERIALS}

The pollution of recipient Sitnica was monitored for a period of time at a point/profile (Vragoli), where already the wastewater from main urban areas is discharged. The monitoring was done by taking water samples on monthly basis and analysing the main parameters according to standard methods [11], conducted in hydrometeorological institute.

In order to meet European standards and requirements of the Urban Wastewater Directive [9], the planning of wastewater treatment facilities for the study area, specifically for municipalities of Prishtina, Fushë Kosovë and Obiliq a number of strategic development options were studied, for which the following technical considerations were taken into account:

- Wastewater treatment plants need to be sited in the lower downstream areas of natural drainage catchments. Pumping of sewage needs to be kept to a minimum, if possible. 
- The hydraulic considerations for locating collector sewers need to be practical and avoid obstructions [7].

- Wastewater treatment plant needs to be located away from other developments, particularly residential, in areas with suitable available land.

For all the studied options the treatment processes were based on biological treatment methods [6].

\section{RESULTS}

The results of the analysed parameters in river Sitnica (Vragoli - monitoring station) are presented in Table I.

The four studied options for wastewater collection and treatment infrastructure in the defined study area are as follows:

Option 1: Places the main wastewater treatment plant at the lowest point of the Prishtevka catchment area, at the confluence with the Sitnica river. At this point most of the sewage flows from Prishtina will drain by gravity but a large part of the sewage collected in Fushë Kosovë will require to be pumped back up to the wastewater treatment plant. A second wastewater treatment plant located near Obiliq will treat water coming from north west of Prishtina and Obiliq.

Option 2: This proposal is similar to option 1 except that a separate wastewater treatment plant is not planned for Obiliq and the sewage is pumped from Obiliq to the wastewater treatment plant near Fushë Kosovë.

Option 3: This option utilises the natural gradients to collect all sewage by gravity and locates the main Prishtina wastewater treatment plant close to the city and second wastewater treatment plant near Obliq for sewage coming from Fushë Kosovë and Obiliq.

Option 4: A variation of option 3 where, in this case, the Fushë Kosovë and Obiliq wastewater treatment plant is located closer to Fushë Kosovë and the sewage pumped back from Obiliq.

By the end of the planning period to 2040 it is estimated there will be sewage flows from around 500,000 inhabitants. When nondomestic flows and infiltration are taken into account the calculated flow requiring treatment is $70,776 \mathrm{~m}^{3} /$ day, or $819 \mathrm{~L} / \mathrm{s}$ [4].

\begin{tabular}{|c|c|c|c|c|c|c|c|}
\hline Parameter & Unit & 2014 & 2015 & 2016 & 2017 & 2018 & $\begin{array}{l}\text { Limit values according to } \\
\text { national legislation A.I. } \\
16 / 2017 \text { (moderate values) }\end{array}$ \\
\hline Turbidity & NTU & 17.9 & 23.5 & 8.1 & 12.8 & 52.1 & \\
\hline $\begin{array}{l}\text { Electrical } \\
\text { conductivity }\end{array}$ & $\mu \mathrm{S} / \mathrm{cm}$ & 665.0 & 630.0 & 693.8 & 655.0 & 546.7 & \\
\hline $\begin{array}{l}\text { Total dissolved } \\
\text { material }\end{array}$ & $\mathrm{mg} / \mathrm{L}$ & 334.4 & 312.5 & 346.9 & 327.1 & 273.3 & \\
\hline $\mathrm{pH}$ & & 7.5 & 7.4 & 8.0 & 7.2 & 7.1 & $7.0-9.0$ \\
\hline Dissolved oxygen & $\mathrm{mg} / \mathrm{L}$ & 4.6 & 6.6 & 5.8 & 4.6 & 6.6 & $6.0-5.0$ \\
\hline Saturation with $\mathrm{O}_{2}$ & $\mathrm{mg} / \mathrm{L}$ & 46.6 & 67.6 & 63.4 & 49.0 & 68.2 & \\
\hline COD & $\mathrm{mg} \mathrm{O}_{2} / \mathrm{L}$ & 9.7 & 43.2 & 42.8 & 43.9 & 117.2 & $7.0-12.0$ \\
\hline $\mathrm{BOD}_{5}$ & $\mathrm{mg} \mathrm{O}_{2} / \mathrm{L}$ & 3.6 & 17.2 & 22.5 & 31.4 & 40.3 & $6.0-8.0$ \\
\hline Total organic carbon & $\mathrm{mg} / \mathrm{L}$ & 2.8 & 12.3 & 15.5 & 20.7 & 29.6 & \\
\hline $\begin{array}{l}\text { Total Suspended } \\
\text { Solids }\end{array}$ & $\mathrm{mg} / \mathrm{L}$ & 25.4 & 23.4 & 13.3 & 10.3 & 98.9 & \\
\hline Detergents & $\mathrm{mg} / \mathrm{L}$ & 0.2 & 0.2 & 0.4 & 0.1 & 0.2 & \\
\hline Nitrates & $\mathrm{mg} / \mathrm{L}$ & 8.6 & 5.4 & 4.8 & 5.2 & 6.4 & $2.0-5.0$ \\
\hline Nitrates N & $\mathrm{mg} / \mathrm{L}$ & 1.9 & 1.2 & 1.1 & 1.2 & 1.4 & \\
\hline Nitrites & $\mathrm{mg} / \mathrm{L}$ & 0.5 & 0.4 & 0.4 & 0.4 & 0.4 & \\
\hline Nitrites N & $\mathrm{mg} / \mathrm{L}$ & 0.1 & 0.1 & 0.1 & 0.1 & 0.1 & \\
\hline Ammonia & $\mathrm{mg} / \mathrm{L}$ & 3.5 & 1.6 & 3.6 & 3.4 & 2.6 & \\
\hline Ammonium $\mathrm{N}$ & $\mathrm{mg} / \mathrm{L}$ & 2.7 & 1.3 & 2.8 & 2.6 & 2.0 & $0.25-0.70$ \\
\hline Total inorganic $\mathrm{N}$ & $\mathrm{mg} / \mathrm{L}$ & 4.2 & 2.6 & 4.0 & 3.9 & 3.3 & \\
\hline $\begin{array}{l}\text { Total N (organic + } \\
\text { inorganic) }\end{array}$ & $\mathrm{mg} / \mathrm{L}$ & 0.0 & 0.0 & 5.6 & 4.5 & 0.0 & $3.0-10.0$ \\
\hline Total organic $\mathrm{N}$ & $\mathrm{mg} / \mathrm{L}$ & 0.0 & 0.0 & 1.5 & 1.2 & 0.0 & \\
\hline Phosphates & $\mathrm{mg} / \mathrm{L}$ & 0.7 & 1.1 & 1.1 & 1.2 & 0.6 & \\
\hline $\begin{array}{l}\text { Orthophosphate } \\
\text { phosphate }\end{array}$ & $\mathrm{mg} / \mathrm{L}$ & 0.2 & 0.4 & 0.4 & 0.4 & 0.2 & $0.1-0.2$ \\
\hline Total P (poli + orto) & $\mathrm{mg} / \mathrm{L}$ & 0.2 & 0.0 & 1.3 & 0.2 & 0.0 & $0.2-0.4$ \\
\hline Sulfates & $\mathrm{mg} / \mathrm{L}$ & 43.1 & 57.0 & 38.9 & 36.0 & 40.9 & \\
\hline Chlorides & $\mathrm{mg} / \mathrm{L}$ & 0.0 & 0.0 & 17.6 & 12.0 & 24.4 & \\
\hline
\end{tabular}

\section{DISCUSSIONS}

The results of the analysed parameters in river Sitnica (Table 1), were confirming the pollution coming from sewage despite that river was doing some self-purification. As seen in the Table 1, the main parameters such as: Dissolved Oxygen, BOD5, COD, Ammonium N, Nitrates etc. are well above the limit values for "moderate type" of river quality according to local legislation (Administrative Instruction $16 / 2017$, Classification of surface water bodies) [12] that transposes the requirements of the EU Water Framework
Directive [9]. Such high value of these parameters shows recent and continues pollution coming from sewage discharges of urban settlements around. Analysing the results of different parameters, we can note that these excesses from year to year become greater. This is due to heavy urbanisation of capital areas and the increase of wastewater discharges. The river is losing the self-purification power and its ecological statues is becoming critical. This water cannot be used safely for any purpose. Graphics of main parameters and their changes/increase through years are shown in Fig. 1. 

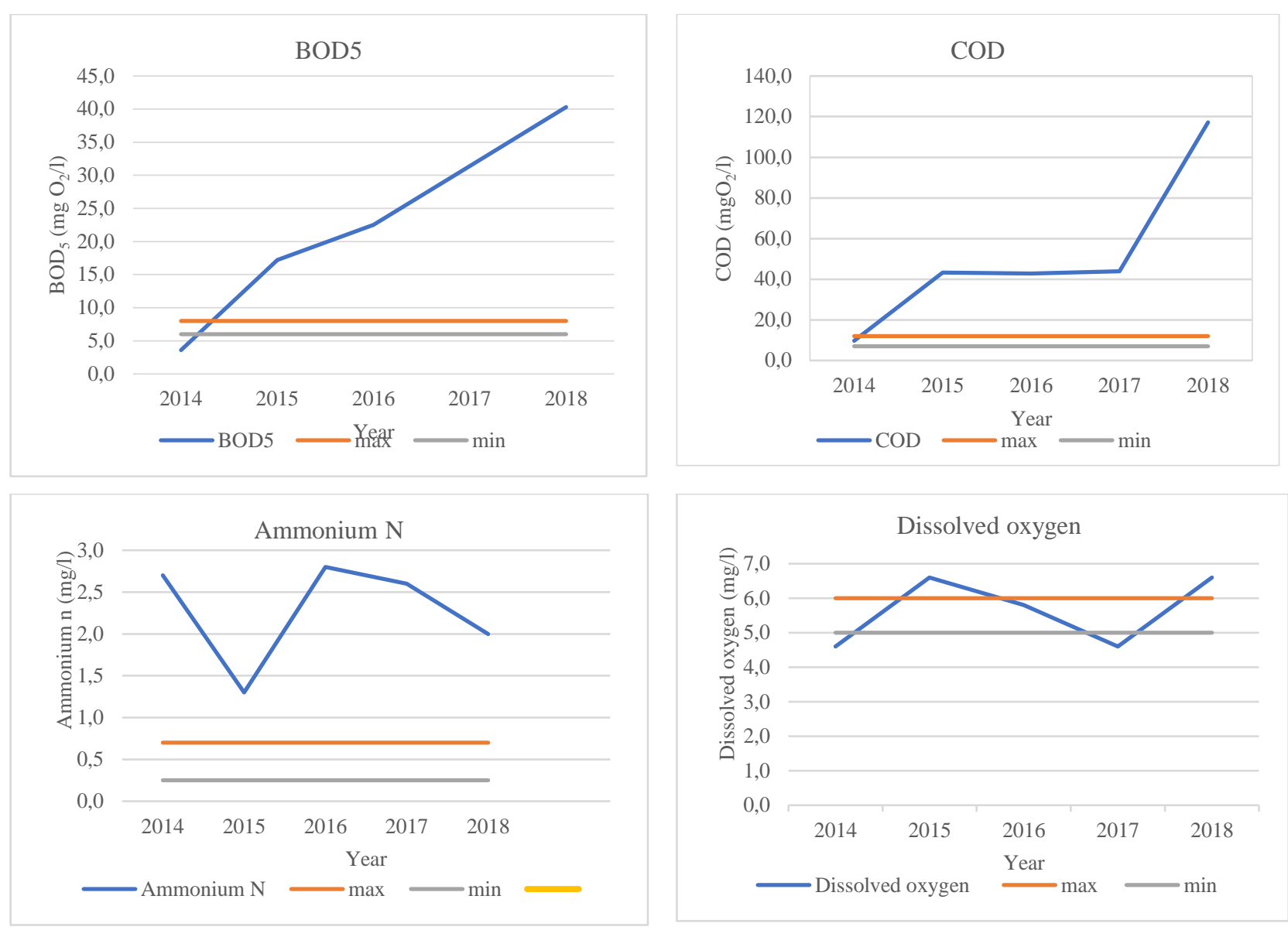

Fig. 1. Graphs of main quality parameters of river Sitnica throughout years 2014-2018.

For construction of a wastewater treatment plant for the capital Prishtina and two nearby towns of Fushë Kosovë and Obiliq, the Option 1 is recommended as best option as shown in Fig. 2.

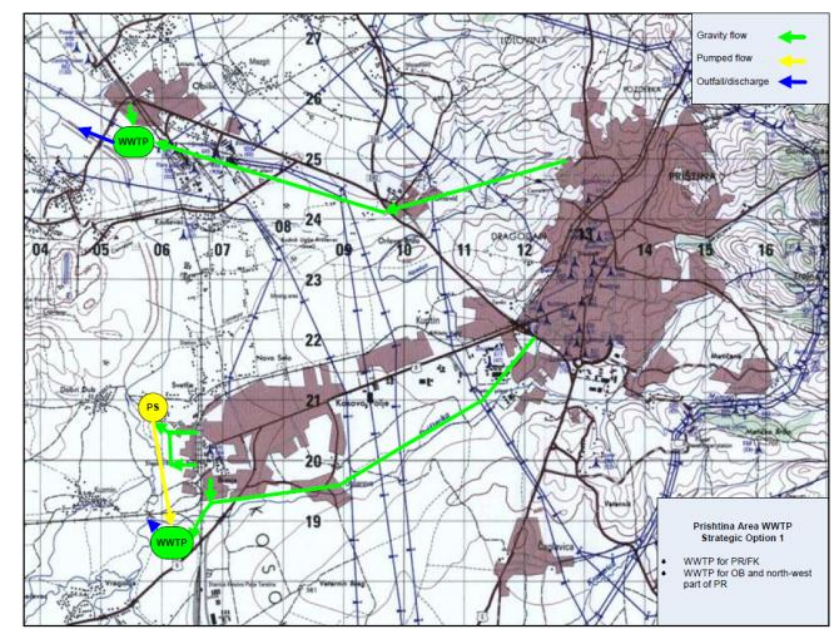

Fig. 2. Proposed option 1 for WWTP in Prishtina.

The proposed option foresees the main wastewater treatment plant at the lowest point of the Prishtevka catchment area, at the confluence with the Sitnica river. At this point most of the sewage flows from Prishtina will drain by gravity but a large part of the sewage collected in Fushë Kosovë will require to be pumped back up to the wastewater treatment plant. A second wastewater treatment plant located near Obiliq will treat water coming from north west of Prishtina and Obiliq.
The proposed design parameters of the wastewater treatment plant in two phases are presented in Table II.

TABLE II: DESIGN PARAMETERS OF WWTP IN PRISHTINA

\begin{tabular}{lccc}
\hline & Unit & Phase 1 & Phase 2 \\
& $\mathrm{p} . \mathrm{e}$. & 439,000 & 439,000 \\
\hline Capacity & $\mathrm{Q}\left(\mathrm{m}^{3} / \mathrm{h}\right)$ & 3,100 & 3,400 \\
$\begin{array}{l}\text { Hydraulic capacity, average daily } \\
\text { flow }\end{array}$ & $\mathrm{Q}\left(\mathrm{m}^{3} / \mathrm{h}\right)$ & 2,600 & 2,800 \\
$\begin{array}{l}\text { Hydraulic capacity, minimum daily } \\
\text { flow }\end{array}$ & $\mathrm{Q}\left(\mathrm{m}^{3} / \mathrm{h}\right)$ & 7,000 & 7,700 \\
$\begin{array}{l}\text { Hydraulic capacity, maximum daily } \\
\text { flow }\end{array}$ & & & \\
\hline
\end{tabular}

The initial phase of construction of wastewater treatment plant for Prishtina, for design horizon 2035, assumes an effluent standard consistent with the Urban Wastewater Directive (UWWTD 91/271/EEC) [10] for non-sensitive waters. To achieve this standard a wastewater treatment plant will require secondary treatment and sludge (biosolids) disposal.

Subsequent development of the wastewater treatment plant beyond 2035 assumes that the receiving waters will be declared sensitive, according to the definition in the UWWTD. Therefore, wastewater treatment plant will require upgrading to include tertiary treatment for removal of nutrients, nitrogen, and phosphorus components.

The recommended treatment process type is a Sequential Batch Reactor (SBR) with primary settlement of sewage. Primary sludge and biological activated sludge will be treated by anaerobic digestion technology. Gas released during anaerobic digestion will be collected and utilized to generate heat and power for operation of the wastewater treatment 
plant itself [8]. Gas storage shall be provided and a combined heat and power (CHP) generator to reduce the reliance of the plant on an external supply of electricity.

The use of this biogas and its bio products that are renewable energy source and environmentally friendly is very limited in Kosovo so, it will be a good example of its production and use for whatever purposes.

From this process it will be produced also sanitary safe fertiliser that can be used in agriculture.

Industrial wastewater discharges will need to be controlled by byelaw in order to protect the fabric of the sewers, to avoid injury to sewerage workers and to preserve the biological treatment process from toxic and inhibitory substances. Some suggested parameters for industrial discharges are as follows:

$$
\begin{array}{lll}
\text { - } & \text { BOD5 concentration: } & \leq 600 \mathrm{mg} / \mathrm{L} ; \\
\text { - } & \text { Effluent temperature: } & \leq 42{ }^{\circ} \mathrm{C} ; \\
\text { - } & \text { pH value: } & 6.0-9.0
\end{array}
$$

\section{CONCLUSIONS}

This study sets several recommendations which provide controlled sewage collection, transportation to wastewater treatment plant location and its appropriate treatment before returning to the nature.

The preservation of surface water quality that is recipient river Sitnica from the sewage, is mayor achievement that study promotes.

Moreover, the study provides opportunity for biogas production that is environmentally friendly biofuel and production of sanitary fertiliser that can be used safely in the agriculture sector.

All this will include the adaptation to climate change and will significantly improve wider public health.

\section{REFERENCES}

[1] State Water Strategy for Kosovo 2017-2036.

[2] Report: State of waters in Kosovo, Kosovo Environmental Protection Agency, 2015.

[3] Report: Annual report of water service providers 2019, Water Regulatory Authority of Kosovo.

[4] Report: TA3-KOS-ENV-01: Project Preparation Feasibility Study for Prishtina Wastewater Treatment Plant, December 2012 Kosovo.

[5] Edited book: E. Roberts Alley, P.E. 2007 Water Quality Control. Mc Graw Hill, WEF PRESS Water Environment Federation Alexandria, Virginia, pp.2.3 -2.7.

[6] Book: Tchobanoglous, G., F. L. Burton and H. D. Stensel, "Wastewater Engineering: Tretament and Reuse", Metcalf \& Eddy, 4th edition, McGraw - Hill, NY, 2003.

[7] Book: Prof.dr. Sylejman Daka, 2018 Sistemet e kanalizimit të vendbanimeve, Fakulteti i Prishtinës.

[8] Book: Ackmez Mudhoo (Editor) 2012 Biogas Production- Pretreatment Methods in Anaerobic Digestion, ISBN: 978-1-11806285-2.

[9] https://ec.europa.eu/environment/water/waterframework/info/intro_en.htm.

[10] https://ec.europa.eu/environment/water/waterurbanwaste/index_en.html.

[11] APHA Standard methods for the examination of water and wastewater, 20th edition, APHA Baltimore, 1998.

[12] Administrative Instruction 16/2017: "Classification of surface water bodies".

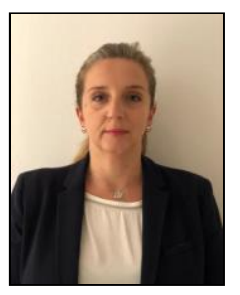

Besime Sh. Kajtazi was born in Mitrovica, Kosovo. She holds Master of Science degree from the Faculty of Civil Engineering, University of Prishtina, Kosovo in 2005.

Since 2006, she works as a Task Manager for water sector in European Union Office in Kosovo. As Task manager in EU office, she ensures effective and efficient programming and implementation of financial assistance in the area of Water and Environment in line with the EU regulations and procedures, ensuring maximum impact to support the EU membership preparation of the beneficiary country (Kosovo).

Mrs Kajtazi is author and co-author of scientific articles in engineering sciences and has participated in national and international conferences. 